The US National Institutes of Health is toughening its funding rules to persuade researchers to share materials more widely. The move is commendable but it raises critical questions that urgently require resolution.

$\mathrm{P}$ rogress in science depends on replication of results, so there is widespread support for the principle that researchers should share the materials needed to reproduce their published claims. Many journals, including Nature, specify this as a condition of publication, and several funding agencies - including the National Institutes of Health (NIH), the Howard Hughes Medical Institute and the Wellcome Trust - expect their researchers to make materials widely available. Even so, failure to share is still common. So we should welcome the NIH's announcement of stronger measures to promote 'good citizenship' in the life-science community.

As reported on page 953, the NIH will soon require grant applications to include a specific plan for sharing model organisms and materials that may result from the funded research. Applicants' track records of sharing will also be taken into consideration when their grants are up for renewal. This policy seems to have teeth, but the NIH has so far published only a brief summary statement. The rules will take effect in October, so there is some urgency to clarify exactly how they will work in practice.

Researchers have many motives for refusing to share published materials. Some - such as a desire to maintain a competitive advantage or to use sharing as a way to leverage honorary co-authorship are contrary to the spirit of publication, and the NIH is right to reject these excuses. But other obstacles to sharing are not so easily dismissed and must still be overcome if the policy is to be effective.

The cost and administrative burden of responding to requests for materials can be substantial, particularly for mice and other animals that are subject to stringent shipping regulations. The NIH has promised to make supplementary funds available to cover these costs, which should help. But academic labs cannot be expected to run animal breeding facilities, so the NIH must also provide strong support for repositories such as the Mutant Mouse Regional Resource Centers, and ensure that they have sufficient capacity to receive and distribute strains in an efficient and timely manner.

Critics of the NIH policy are understandably concerned about intellectual-property rights, but universities are not disinterested observers in the debate. They are entitled to patent their researchers' potentially valuable inventions, and in some cases the imperative to share may clash with the profit motive. In announcing that it will hold not only individual researchers but also their institutions accountable for sharing, the NIH has staked out a strong position. It remains to be seen how it will be implemented.

Refusals to share resources are almost certainly underreported, because researchers whose requests are denied are often reluctant to make a fuss, especially if they believe that nothing can be done. But unless they are willing to report problems, nothing will change.

Journals have a responsibility to pursue complaints, of course, but the real power lies with funding agencies. The NIH has provided a lead; other agencies should now follow to establish consistent and enforceable community standards. These must be embodied in clear policy statements, which must also include contact details for individuals to whom problems can be referred, and clear explanations of how complaints will be handled.

\title{
A matter of interest
}

The biotech industry's top lobbyist faces a problem he was quick to raise as a Congressman: apparent conflict of interest.

$\mathrm{C}$ ongressman James Greenwood (Republican, Pennsylvania) is, on the face of it, a terrific catch for the Biotechnology Industry Organization (BIO), which last month announced his appointment as its next president (see Nature 430, 495; 2004).

Greenwood was, until the announcement, chair of the investigations subcommittee of the House of Representatives energy and commerce committee. His powerful subcommittee has this year been vigorously investigating alleged conflicts of interest among senior scientists at the National Institutes of Health (NIH).

The main outcomes of his investigation, so far, have been twofold: the implementation of stringent rules blocking links between senior NIH scientists and the biotechnology industry, and the tarnishing of the biomedical agency's hitherto pristine image. Some accounts of the hearings have portrayed the NIH as corrupt, spoiling the chances of any further increases in its admittedly generous budget.

$\mathrm{NIH}$ researchers are somewhat flummoxed by news that the man leading the investigation into their links with the biotechnology industry is about to work for it. It looks to them as though Greenwood was sternly demanding that publicly employed scientists steer clear of private-sector involvement, even as he prepared to cash in on his own public service by accepting an annual salary of $\$ 650,000$, plus bonuses, to lobby for an industry that he used to help supervise.

The committee's investigation - sparked by allegations first reported in the Los Angeles Times - found that a small number of individuals at the NIH had succumbed to the temptation of the barrage of offers from industry, and accepted consultancy or speaker fees. Most had done so within their employment rules; a few appear to have breached them.

But the hearings of Greenwood's committee created the impression that links between NIH researchers and biotechnology companies were out of control and corrosive to the public interest. This has created a backlash that is likely to constrict such links for years to come. The integrity of government scientists is a serious matter and an appropriate one for congressional investigation. But it is difficult to see Greenwood's career change as being consistent with the moral thrust of his committee's work.

He has resigned as chair of the committee and will leave Congress in January to work for BIO; under House rules, he is not supposed to lobby former congressional colleagues directly for a year after that. His appointment nonetheless leaves the impression that mid-level and senior NIH researchers are being held to far higher ethical standards than those adhered to by their overseers. 